EREM 77/3

Journal of Environmental Research, Engineering and Management

Vol. 77 / No. 3 / 2021

pp. $15-22$

DOI 10.5755/j01.erem.77.3.29355

\section{Sugar Industry Waste for Bioelectricity Generation}

Received 2021/06

Accepted after revision 2021/08

\title{
Sugar Industry Waste for Bioelectricity Generation
}

\section{Rojas-Flores S.*}

Universidad Señor de Sipan, Peru

\section{R. Nazario-Naveda}

Grupo de Investigación en Ciencias Aplicadas y Nuevas Tecnologías, Universidad Privada del Norte,

Trujillo, 13007, Peru

\section{Santiago M. Benites, De La Cruz -Noriega M., Cabanillas-Chirinos L.}

Instituto de Investigación en Ciencias y Tecnología de la Universidad Cesar Vallejo,

Trujillo, 13001, Peru

\section{Valdiviezo-Dominguez F.}

Escuela de Ingeniería Ambiental, Facultad de Ingeniería, Universidad Cesar Vallejo,

Trujillo, 13001, Peru

*Corresponding author: segundo.rojas.89@gmail.com

Microbial fuel cells are presented as the promise of technology to generate electricity by using organic waste. In this research, molasses waste from Laredo Agroindustrial Company was used as fuel, as well as graphite and zinc electrodes, managing to build low-cost cells. It was possible to generate voltage and current peaks of $0.389 \pm 0.021$ $\mathrm{V}$ and $1.179 \pm 0.079 \mathrm{~mA}$, respectively. The cells showed that acid $\mathrm{pH}$ levels and conductivity values were around 100 $\mathrm{mS} / \mathrm{cm}$ during the period of the highest bioelectricity generation. The maximum power density was $3.76 \pm 0.62 \mathrm{~W} /$ $\mathrm{cm}^{2}$ for a current density of $247.55 \mathrm{~mA} / \mathrm{cm}^{2}$, showing a peak voltage of $0.459 \pm 0.52 \mathrm{~V}$. The yeasts showed a logarithmic phase up to day 25 reflecting an increase in cell growth. Microbial fuel cells are projected to be the most viable solution for organic waste and clean energy generation problems.

Keywords: waste, molasses, generation, agro-industry, electricity. 


\section{Introduction}

The main source of energy for economic and social development in the past century was fossil fuels. Their discovery has led society to develop its various activities based on these fuels, which has generated great problems, on the one hand, due to their finite nature and the negative impacts they generate on the environment because of the emission of greenhouse gases (Matsuoka et al., 2015), such as carbon dioxide $\left(\mathrm{CO}_{2}\right)$, nitrogen oxides $\mathrm{NO}_{x}\left(\mathrm{~N}_{2} \mathrm{O}, \mathrm{NO}\right.$ and $\left.\mathrm{NO}_{2}\right)$, sulfur oxides $\mathrm{SO}_{x}\left(\mathrm{SO}_{2}\right.$ and $\left.\mathrm{SO}_{3}\right)$, volatile organic compounds, among other gases (Sayed et al., 2021). It is therefore vital to develop new sources of energy generation that meet the world's energy needs without compromising the sustainability of the planet. Within the development of energy alternatives, we find the energy obtained from biomass that represents a source of sustainable and renewable production in the future (Do et al., 2020). This is how microbial fuel cells (MFC) emerge, which have gained great attention due to their capacity to generate energy from organic or inorganic compounds through microorganisms (Das, 2017). In these electrochemical devices, organic waste degrades to smaller molecules (Hemalatha et al., 2020) because of microorganisms that play an essential role as they form biofilms in the anode chamber where substrates are oxidized generating electrons, protons and other metabolites. There are single-chamber microbial fuel cells, which have a cathode electrode that is, on one side, in contact with liquid and, on the other, is directly exposed to air. Various studies, such as the one conducted by Guo et al. (2021) showed that single-chamber MFCs, in the absence of a membrane, generate higher output power; therefore, in this study, this design was chosen because they are simpler, as well as economical to build. MFCs can also operate at room temperature and atmospheric pressure (Hemalatha et al., 2020); it is possible to use a wide range of substrates, such as soil sediments, organic waste, among others. Molasses is among these substrates that can be used in MFCs. This is an important by-product resulting from the refinement of sugar cane (Saccharum officinarum). This substrate has great potential for power generation, for its high content of fructose and glucose, and is readily available (Liang et al., 2020).
In this sense, worldwide, in 2019, 194 million tons of sugar cane were generated, standing out America, Africa and Asia with the most significant productions; as for countries, Brazil stands out with a production of 604 million tons of sugar cane between 2000 and 2019, followed by India and China with lower production (Risco, 2019). In the case of Peru, sugar cane is produced in three regions of the country: on the coast, with high production, concentrated in the north, such as La Libertad and Lambayeque; in the jungle, in the department of San Martín; and, in the highlands, all year round (Carpio Carrillo, 2019). There are a variety of research works on the generation of energy from molasses in microbial fuel cells. For example, Pandit et al. (2014) studied improved energy recovery from cane molasses by using microbial fuel cells, where they generated biohydrogen from the fermentation of cane molasses and electrical energy, obtaining an output power of $3.02 \mathrm{~W} / \mathrm{m}^{3}$. They concluded that the integration of an MFC is a promising way to use the energy of that substrate.

This research aims to give added value to one of the residues of sugar cane, molasses, by using it as substrate in a single-chamber microbial combustion cell. Therefore, the values of voltage, current, conductivity, $\mathrm{pH}$, degrees Brix, current density and power density were monitored. A yeast count was also performed and the biofilms of the cathode and anode electrode were analyzed. This molasses treatment alternative represents an eco-friendly method.

\section{Materials and Methods}

\section{A. Construction of single-chamber microbial fuel cells}

MFCs were constructed by using polymethylmethacrylate tubes of 5 and $20 \mathrm{~cm}$ in diameter and length, respectively, and at their ends, electrodes of zinc (Zn) and graphite (GR) of 5 and $0.05 \mathrm{~cm}$ in diameter and thickness were placed. $\mathrm{Cu}$ wires $(12 \mathrm{~mm}$ diameter) were welded to the electrodes. Finally, the MFCs were encapsulated by using an acrylic box to avoid any external contamination, as shown in Fig. 1. 
Fig. 1. Scheme of the MFC prototype

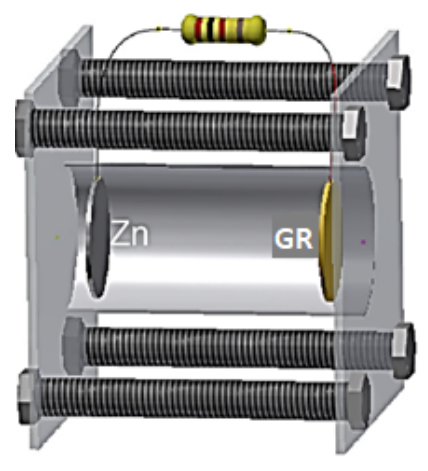

\section{B. Sampling and bio-electrochemical analysis}

One liter of molasses waste was collected in hermetic bottles from Laredo Agroindustrial Company. Initial parameters of $\mathrm{pH}$, brix, voltage, electric current, power, current density, power density, volumetric power, and yeast count were measured.

\section{B.1 Isolation and identification of microorganisms}

\section{B.1.1. Isolation of microorganisms from the cathode in solid media}

Swabs of the cathode plate were performed and sown by stria in culture media of Agar MacConkey, Nutrient Agar and Sabouraud Agar. They were incubated at temperatures of $35^{\circ} \mathrm{C}$ and $44.5^{\circ} \mathrm{C}$ (for the isolation of total coliforms) and $30^{\circ} \mathrm{C}$ for yeasts. The cultures were performed in duplicate.

\section{B.1.2. Biochemical identification of yeasts}

Axenic (or pure) cultures were made from characteristic yeast colonies. Sabouraud Agar slant culture media contained in screw cap tubes were used. The identification of genus and species was carried out, recording the microscopic characteristics of oval cells in the process of gemmation (see Fig. 2 (a)), macroscopic white-colored smooth glossy colonies, with edges that vary from entire to lobulated, which are characteristic of the genus Candida (see Fig. 2 (b)).

Fig. 2. a) Microscopy of Candida pelliculose with Gram staining (100X) and b) A macroscopic view of C. pelliculose colonies on Sabouraud Agar with black background

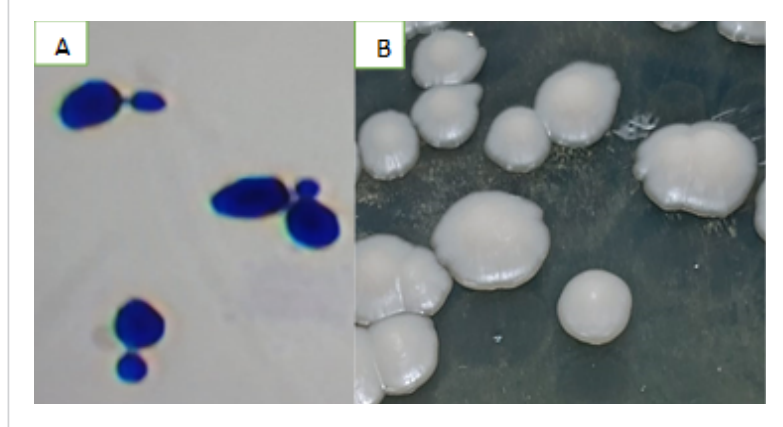

On the other hand, Fig. 3 shows the reading of the microbial identification made by using the API 20 C AUX system of BIOMERIEUX (González Castroagudín, 2017), in which a score is obtained based on each test either positive or negative. The numerical identification of an observed profile is supported by the calculation of its proximity to the different taxa in the database and to the most typical profile in each taxon. Finally, the classification of taxa allowed obtaining an identification result (Gobernado et al., 2021). Subsequently, the results were entered in the API WEB software to determine the genus and bacterial species (API ${ }^{\circledR}$ Reference) confirming that the yeast under study is $C$. pelliculose, with an ID of $98.9 \%$ in the microbial identification system API 20 C AUX. According to Jimoh et al. (2012), it is indicated

Fig. 3. API 20 C AUX identification for C. pelliculose (98.9\% ID)

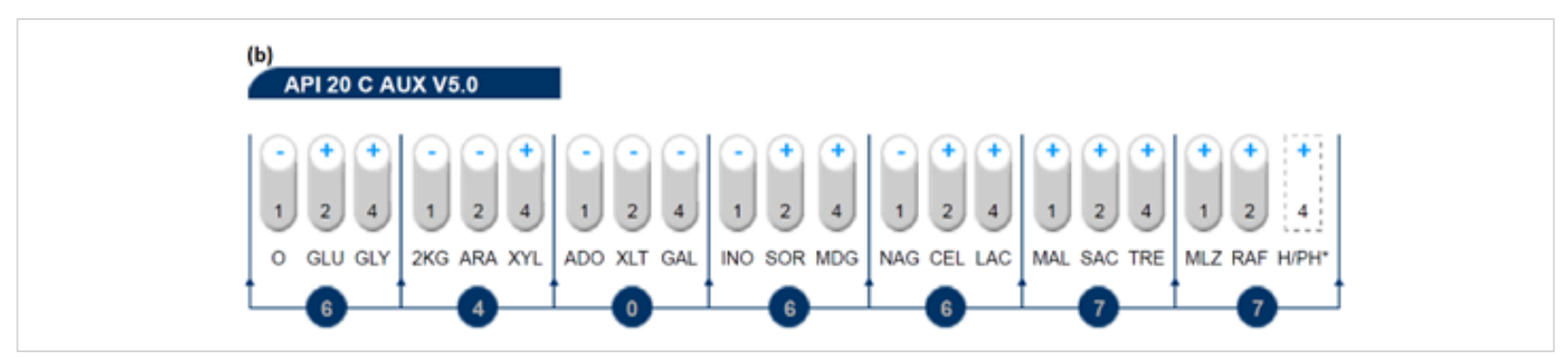


that, as spontaneous fermentation advances, there are several species of yeast involved. In the production of fermented beverages in Nigeria, the following yeasts were isolated: S. cerevisiae, C. colliculosa, Candida utilis, Candida magnolia, R. mucilaginosa, Trichosporon asahii, Candida pelliculose and Cryptococcus albidus.

\section{1 Physico-chemical characterization of MFCs}

MFCs were monitored for 30 days at room temperature $\left(\sim 21.5^{\circ} \mathrm{C}\right)$, in which voltage and current variations were observed by using a multimeter (Prasek Premium PR85). Meanwhile, for current and power density measurements, the formulae used by Rojas et al. (2020) were used, where power density (PD) and current density (CD) were calculated by using external resistors (Rext.) of 2.4, $9.9,19.8,29.6,49.2,192.2,384,564,812$ and $996 \Omega$ in the formulae $P D=V_{\text {cell }}^{2} /\left(R_{\text {ext. }} A\right)$ and $C D=V_{\text {cell }} /\left(R_{\text {ext. }} A\right)$; where $V_{\text {cell }}$ is the voltage of MFC and the area (A) is $78.5 \mathrm{~cm}^{2}$. Conductivity (Conductivity meter CD-430), $\mathrm{pH}$ (pH meter 110 series Oakton) and degrees Brix (RHB-32 brix refractometer) were also monitored.

\section{Results and Discussion}

In Fig. 4 (a), the average values of the generated voltages of MFCs during a period of 30 days are observed. MFCs increased their values from the first day of monitoring until day 16 , where a maximum peak of approximately $0.389 \pm 0.021 \mathrm{~V}$ is observed and, then, it falls until the last day $(0.144 \pm 0.032 \mathrm{~V})$. This research generated higher voltage compared with others. For example, in the research work carried out by Guo et al. (2016), its double chamber cells with catalyst substrates for oxygen reduction generated a peak voltage of $305 \mathrm{mV}$. Likewise, the research work carried out by Morris et al. (2007), in which groundwater containing petroleum hydrocarbons was used as a substrate, managed to generate $250 \mathrm{mV}$ after the formation of the biofilm. In Fig. 4 (b), the electrical current values generated during the monitoring period are shown; the values increase slightly from the first day $(0.52 \pm 0.039 \mathrm{~mA})$ to day $19(1.179 \pm 0.079 \mathrm{~mA})$, after which the loss of electrical current until the last day $(0.707 \pm 0.104 \mathrm{~mA})$ of monitoring is noticed. The generation of electricity is mainly due to the oxidation of organic matter (molasses waste) from where they produce electrons and are captured by the anode electrode, and pass to the cathode electrode generating a flow of electrons (Saha et al., 2019). The type of substrate is important for any type of biological process, because it serves as a source of carbon (nutrient) and energy (Oyiwona et al., 2018), likewise, the efficiency and economic feasibility of changing organic waste into bioenergy depending on its characteristics and component of the waste material (Igboamalu et al., 2019; Ong and Yamagiwa, 2018).

Fig. 4. Monitoring the generation of (a) voltage and (b) current of MFCs
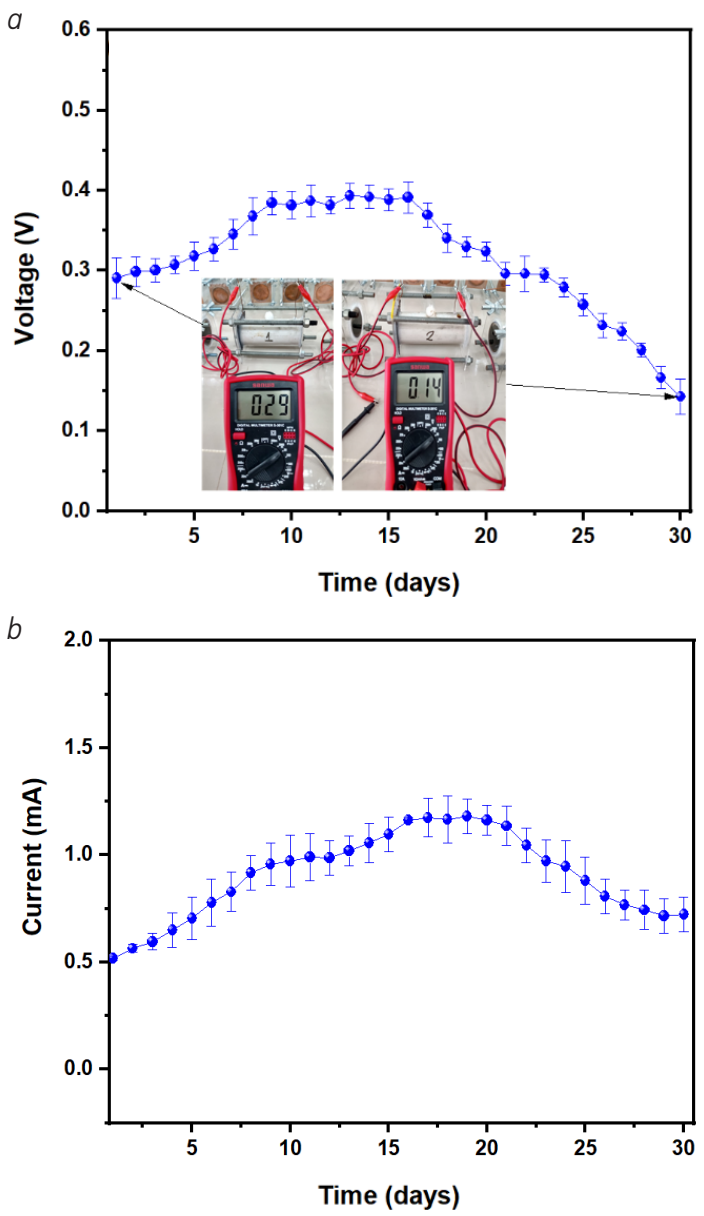

In Fig. 5 (a), the pH values of MFCs are observed. The values increase slightly from the first (4.98) to the last (6.25 \pm 0.079 ) day, resulting in a pH of $5.90 \pm 0.081$ (from day 19) where a peak voltage value was generated. The increase in $\mathrm{pH}$ values is mainly due to microbial activity, 
exactly when bacteria approached the stationary or death phase. During this period, large numbers of dead microorganisms were observed settling at the bottom of the reactor (Li et al., 2021; Tamilarasan et al., 2017). In Fig.

Fig. 5. Monitoring of values of (a) $\mathrm{pH}$, (b) conductivity and (c) degrees Brix of MFCs for 30 days

$a$

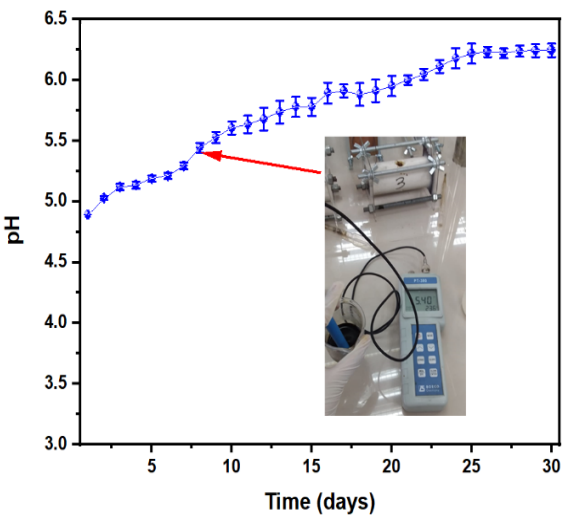

$b$

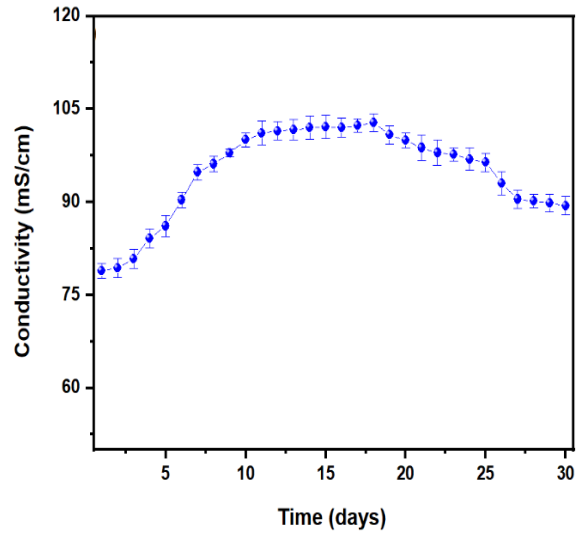

c

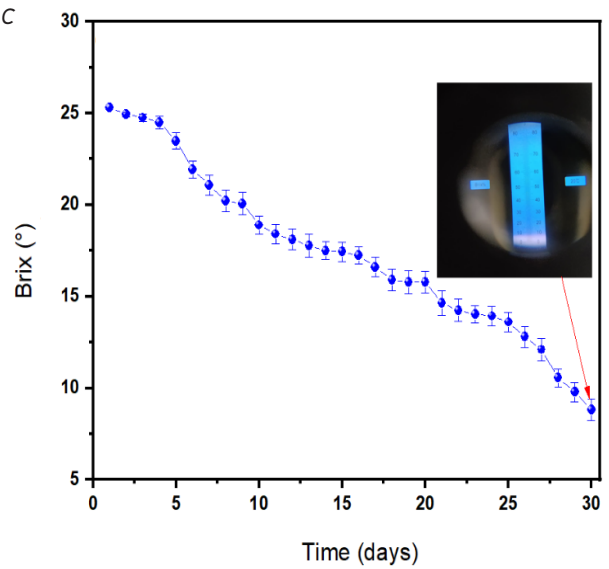

5 (b), conductivity values are observed, which increase from day $1(79.1 \pm 0.03 \mathrm{mS} / \mathrm{cm})$ to day $10(100 \pm 0.23$ $\mathrm{mS} / \mathrm{cm}$ ), time in which it remains slightly constant until day $18(102 \pm 0.31 \mathrm{mS} / \mathrm{cm})$, and, finally, it descends slightly to the last day $(89.12 \pm 0.65 \mathrm{mS} / \mathrm{cm})$. In Fig. 5 (c), the decrease of the values of degrees Brix, from 25.4 to 8.6 on the first and the last day, respectively, is observed. The values of power density (PD) and current density (CD) of microbial fuel cells are shown in Fig. 6. The PDMAX. shown was $3.76 \pm 0.62 \mathrm{~W} / \mathrm{cm}^{2}$ in a CD of $247.55 \mathrm{~mA} /$ $\mathrm{cm}^{2}$, with a peak voltage of $0.459 \pm 0.52 \mathrm{~V}$. The values obtained in this work exceed those reported in Tamilarasan et al.'s (2017) study, in which wastewater from the treatment of surgical cotton was used as substrate (fuel), achieving a $P D_{\max }$ of $0.119 \mathrm{~W} / \mathrm{m}^{2}$ in a $C D$ of approximately $130.5 \mathrm{~mA} / \mathrm{m}^{2}$. In the same way, Michalopoulos et al. (2017) generated lower values of PD $\left(\sim 54 \mathrm{~mW} / \mathrm{m}^{3}\right)$ and $\mathrm{CD}\left(\sim 150 \mathrm{~mA} / \mathrm{cm}^{2}\right)$ by using the liquid fraction of a mixture of organic residues and cheese whey as fuel in a double-chamber cell.

In Fig.7 (a), the graph is observed in relation to the biomass concentration over a period of 30 days, where a logarithmic phase that lasted for 25 days was observed, reflecting increased cell growth due to the fact that, at this phase, yeasts consume nutrients by releasing electrons from organic substrates (Ayodele et al., 2020; Sedky et al., 2019), such as sugar cane molasses with approximately $50 \%$ fermentable sugar content, 30-36 $\%$ sucrose, 10-17 \% (fructose + glucose), polysaccharides, organic acids, proteins, among others (Rodicio

Fig. 6. Values of current density and power density in MFCs

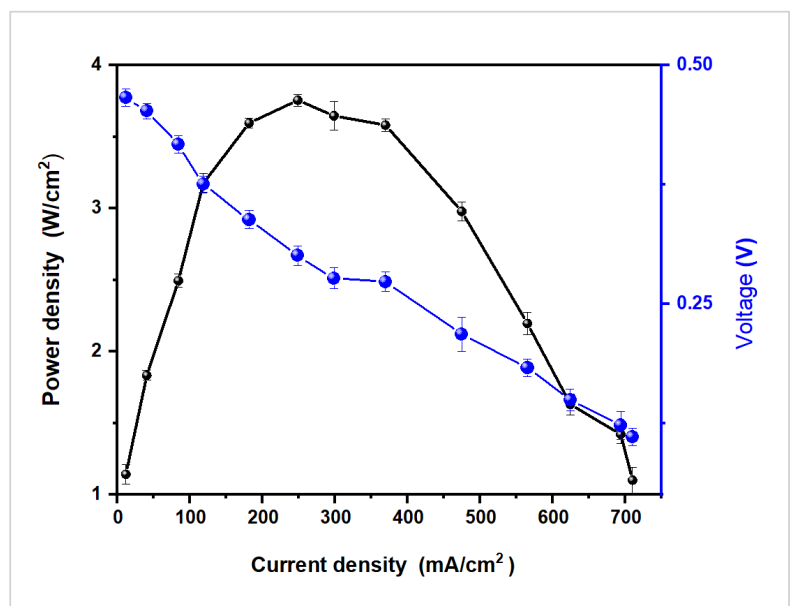


and Heinisch, 2017). These sugars are an excellent source of carbon for yeasts that present different enzymatic complexes responsible for electron transport reactions (Suarez-Diez et al., 2020). These enzymes are able to decompose various substrates, mainly, sugars, through two metabolic pathways, respiration and fermentation, which begin with glycolysis, resulting in the production of two molecules of pyruvate and ATP per glucose (Perez-Samper et al., 2018). Fig. 7 (b) shows the result that was entered in the API WEB software to determine the genus and bacterial species (API ${ }^{\circledR}$ Reference) confirming that the yeast under study is C. pelliculose, with an ID of $98.9 \%$ in the microbial identification system API 20 C AUX.

Fig. 7. Values for (a) yeast count and (b) API 20 C AUX

$a$

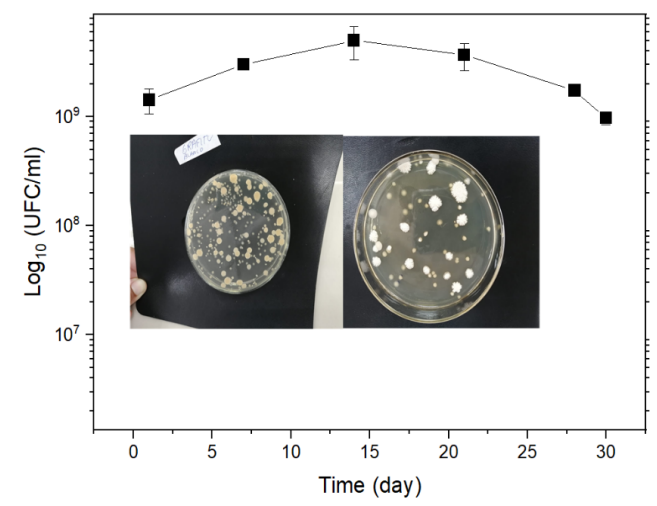

$b$

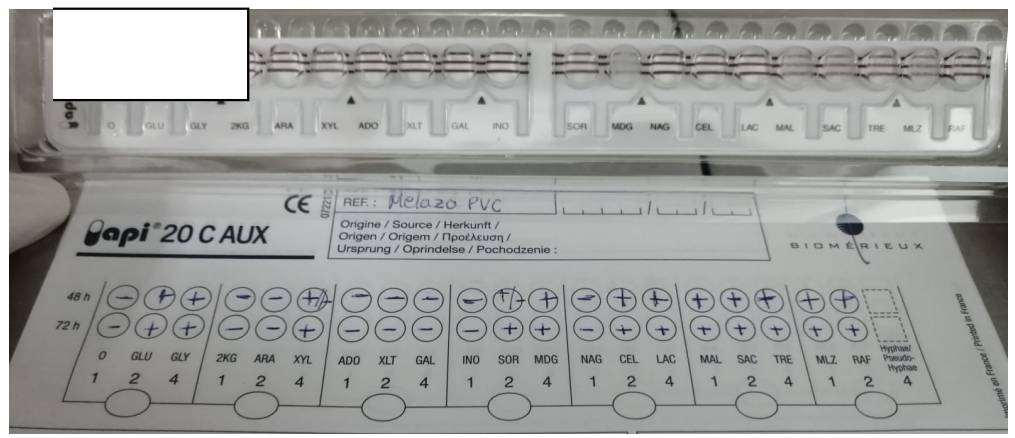

\section{Conclusions}

It was successfully verified that the use of agro-industrial waste, such as molasses waste from Laredo Agroindustrial Company, managed to generate bioelectricity with maximum voltage and current peaks of $0.389 \pm 0.021 \mathrm{~V}$ and $1.179 \pm 0.079 \mathrm{~mA}$, respectively. $\mathrm{PH}$ levels were always within the limits of the acidic lev$\mathrm{el}$, while conductivity values were approximately within the values of $100 \mathrm{mS} / \mathrm{cm}$ during the period of greatest electricity generation, and the degrees Brix always went down from day one to the last day. $\mathrm{PD}_{\text {MAX }}$. was $3.76 \pm$ $0.62 \mathrm{~W} / \mathrm{cm}^{2}$ for a CD of $247.55 \mathrm{~mA} / \mathrm{cm}^{2}$, showing a peak voltage of $0.459 \pm 0.52 \mathrm{~V}$. In the yeast count, a logarithmic phase was observed until day 25 reflecting an increase in cell growth. This research work provides an eco-friendly solution for agro-industrial companies to generate their own electricity and reduce costs. 


\section{References}

API ${ }^{\circledR}$ Reference Guide API ${ }^{\circledR}$ REFERENCE GUIDE. (n.d.). https:// www.biomerieux-usa.com/sites/subsidiary_us/files/18_apiref-guide_v7.pdf

Ayodele, B. V., Alsaffar, M. A., and Mustapa, S. I. (2020). An overview of integration opportunities for sustainable bioethanol production from first-and second-generation sugar-based feedstocks. Journal of Cleaner Production, 245, 118857. https:// doi.org/10.1016/j.jclepro.2019.118857

Carpio Carrillo, A. C. (2019). PRODUCCIÓN DE LA CAÑA DE AZÚCAR (Bachelor's thesis, Instituto Superior Tecnológico Bolivariano de Tecnología). Pandit, S., Balachandar, G., and Das, D. (2014). Improved energy recovery from dark fermented cane molasses using microbial fuel cells. Frontiers of Chemical Science and Engineering, 8(1), 43-54. https://doi.org/10.1007/ s11705-014-1403-4

Das, D. (2017). Microbial Fuel Cell- Introduction. Springer Nature, 1-19. https://doi.org/10.1007/978-3-319-66793-5_1

Do, M. H., Ngo, H. H., Guo, W., Chang, S. W., Nguyen, D. D., Liu, Y., ... and Kumar, M. (2020). Microbial fuel cell-based biosensor for online monitoring wastewater quality: A critical review. Science of The Total Environment, 712, 135612.Parkash, A. (2016). Microbial Fuel Cells: A Source of Bioenergy. Journal of Microbial and Biochemical Technology, 8(3). https://doi. org/10.4172/1948-5948.1000293

Gobernado, M. y López, J. Identificación bacteriana. (2021). Elsevier.es. https://www.elsevier.es/es-revista-enfermedades-infecciosas-microbiologia-clinica-28-pdf-13059086

González Castroagudín, S. (2017). Sífilis, tuberculosis y alimentación, la obra de Enrique Hervada García-Sampedro (1883-1953) y la salud materno-infantil.API ${ }^{\circledR}$ Reference Guide API ${ }^{\circledR}$ REFERENCE GUIDE. (n.d.).

Guo, D., Shibuya, R., Akiba, C., Saji, S., Kondo, T., and Nakamura, J. (2016). Active sites of nitrogen-doped carbon materials for oxygen reduction reaction clarified using model catalysts. Science, 351(6271), 361-365. https://doi.org/10.1126/science.aad0832

Guo, F., Liu, Y., and Liu, H. (2021). Hibernations of electroactive bacteria provide insights into the flexible and robust BOD detection using microbial fuel cell-based biosensors. Science of The Total Environment, 753, 142244. https://doi.org/10.1016/j. scitotenv.2020.142244

Hemalatha, M., Sravan, J. S., and Mohan, S. V. (2020). Self-induced bioelectro-potential influence on sulfate removal and desalination in microbial fuel cell. Bioresource technology, 309, 123326.Du, Z., Li, H., and Gu, T. (2007). A state of the art review on microbial fuel cells: A promising technology for wastewater treatment and bioenergy. Biotechnology Advances, 25(5), 464482. https://doi.org/10.1016/j.biotechadv.2007.05.004

Hemalatha, M., Sravan, J. S., and Mohan, S. V. (2020). Self-induced bioelectro-potential influence on sulfate removal and desalination in microbial fuel cell. Bioresource technology, 309, 123326. https://doi.org/10.1016/j.biortech.2020.123326

Igboamalu, T. E., Bezuidenhout, N., Matsena, M. T., and Chirwa, E. (2019). Microbial fuel cell power output and growth: effect of $\mathrm{pH}$ on anaerobic microbe consortium.

Jimoh, S. O., Ado, S. A., Ameh, J. B., and Whong, C. M. (2012). Characteristics and diversity of yeast in locally fermented beverages sold in Nigeria. World J. Eng. Pure Appl. Sci, 2, 40-44.

Liang, Y., Yu, S., Zhen, Z., Zhao, Y., Deng, J., and Jiang, W. (2020). Climatic change impacts on Chinese sugarcane planting: Benefits and risks. Physics and Chemistry of the Earth, Parts A/B/C, 116, 102856. https://doi.org/10.1016/j.pce.2020.102856

Li Li, Dai Qin, Zhang Sai, and Liu Hao. (2021). The degradation efficiency and mechanism of sulfur-containing azo dye wastewater by microbial fuel cells at different $\mathrm{pH}$. Journal of Environmental Engineering, 15(1), 1-11.

Matsuoka, S., Bressiani, J., Maccheroni, W., and Fouto, I. (2015). Sugarcane Bioenergy. Sugarcane, 383-405. https://doi.org/10.1016/ B978-0-12-802239-9.00018-9

Michalopoulos, I., Chatzikonstantinou, D., Mathioudakis, D., Vaiopoulos, I., Tremouli, A., Georgiopoulou, M., ... and Lyberatos, G. (2017). Valorization of the liquid fraction of a mixture of livestock waste and cheese whey for biogas production through high-rate anaerobic co-digestion and for electricity production in a microbial fuel cell (MFC). Waste and Biomass Valorization, 8(5), 1759-1769. https://doi.org/10.1007/s12649-017-9974-1

Morris, J. M., Jin, S., Wang, J., Zhu, C., and Urynowicz, M. A. (2007). Lead dioxide as an alternative catalyst to platinum in microbial fuel cells. Electrochemistry communications, 9(7), 1730-1734. https://doi.org/10.1016/j.elecom.2007.03.028

Ong, S. A., and Yamagiwa, K. (2018). Evaluation on the electricity generation using membrane-less fixed-bed upflow microbial fuel cell. Rendiconti Lincei. Scienze Fisiche e Naturali, 29(1), 103-107. https://doi.org/10.1007/s12210-018-0665-z

Oyiwona, G. E., Ogbonna, J. C., Anyanwu, C. U., and Okabe, S. (2018). Electricity generation potential of poultry droppings wastewater in microbial fuel cell using rice husk charcoal electrodes. Bioresources and Bioprocessing, 5(1), 1-6. https://doi. org/10.1186/s40643-018-0201-0

Pandit, S., Balachandar, G., and Das, D. (2014). Improved energy recovery from dark fermented cane molasses using microbial 
fuel cells. Frontiers of Chemical Science and Engineering, 8(1), 43-54.. https://doi.org/10.1007/s11705-014-1403-4

Perez-Samper, G., Cerulus, B., Jariani, A., Vermeersch, L., Barrajón Simancas, N., Bisschops, M. M., ... and Verstrepen, K. J. (2018). The Crabtree effect shapes the Saccharomyces cerevisiae lag phase during the switch between different carbon sources. MBio, 9(5), e01331-18. https://doi.org/10.1128/mBio.01331-18

Risco Vera, C. T. (2019). Efectos del cadmio sobre la germinación y biomasa en variedades de caña de azúcar de la cuenca baja del Guayas (Bachelor's thesis, Facultad de Ciencias Naturales. Universidad de Guayaquil).

Rodicio, R., and Heinisch, J. J. (2017). Carbohydrate metabolism in wine yeasts. In Biology of Microorganisms on Grapes, in Must and in Wine (pp. 189-213). Springer, Cham. https://doi. org/10.1007/978-3-319-60021-5_8

Rojas-Flores, S., Noriega, M. D. L. C., Benites, S. M., Gonzales, G. A., Salinas, A. S., and Palacios, F. S. (2020). Generation of bioelectricity from fruit waste. Energy Reports, 6, 37-42 https:// doi.org/10.1016/j.egyr.2020.10.025

Saha, T. C., Protity, A. T., Zohora, F. T., Shaha, M., Ahmed, I., Barua, E., ... and Salimullah, M. (2019). Microbial Fuel Cell (MFC) Application for Generation of Electricity from Dumping Rubbish and Identification of Potential Electrogenic Bacteria. Adv. Ind. Biotechnol, 2(10). https://doi.org/10.24966/AIB-5665/100010

Sayed, E. T., Wilberforce, T., Elsaid, K., Rabaia, M. K. H., Abdelkareem, M. A., Chae, K.-J., and Olabi, A. G. (2021). A critical review on environmental impacts of renewable energy systems and mitigation strategies: Wind, hydro, biomass and geothermal. Science of The Total Environment, 766, 144505. https://doi. org/10.1016/j.scitotenv.2020.144505

Sedky, H., Abd, A., Rehab, M. (2019). Electricity generation from sugarcane molasses using microbial fuel cell technologies. Energy, 178, 538-543. https://doi.org/10.1016/j.energy.2019.04.087

Suarez-Diez, M., Porras, S., Laguna-Teno, F., Schaap, P. J., and Tamayo-Ramos, J. A. (2020). Toxicological response of the model fungus Saccharomyces cerevisiae to different concentrations of commercial graphene nanoplatelets. Scientific reports, 10(1), 1-12. https://doi.org/10.1038/s41598-020-60101-7

Tamilarasan, K., Banu, J. R., Jayashree, C., Yogalakshmi, K. N., and Gokulakrishnan, K. (2017). Effect of organic loading rate on electricity generating potential of upflow anaerobic microbial fuel cell treating surgical cotton industry wastewater. Journal of environmental chemical engineering, 5(1), 1021-1026. https:// doi.org/10.1016/j.jece.2017.01.025 